\title{
Supermadres, Maternal Legacies and Women's Political Participation in Contemporary Latin America
}

\author{
SUSAN FRANCESCHET, JENNIFER M. PISCOPO and \\ GWYNN THOMAS*
}

Abstract. Elsa Chaney once argued that Latin American women turned to motherhood to justify their political participation. Now that Latin American women have gained unprecedented access to national-level office, we ask whether these cultural narratives of maternalism still condition female politicians' access to political power. Using public opinion data, media analysis, and elite interviews, we conceptualise four strategic frames deployed by elite women to justify their national-level political careers: the traditional supermadre, the technocratic caretaker, the macho minimiser, and the difference denier. We argue that while today's female politicians have developed diverse responses to maternalism, their access to public office remains profoundly shaped by structural constraints and cultural narratives that privilege traditional feminine ideals of caretaking.

Keywords: gender, politics, women, motherhood, Latin America

\section{Introduction}

Motherhood has been central to women's engagement with politics in Latin America. First-wave women's movements grounded their suffrage demands

Susan Franceschet is a Professor of Political Science at the University of Calgary. Email: sfrances@ucalgary.ca. Jennifer M. Piscopo is an Assistant Professor of Politics at Occidental College. Email: piscopo@oxy.edu. Gwynn Thomas is an Associate Professor of Global Gender Studies at University at Buffalo, SUNY. Email: gmthomas@buffalo.edu.

* We are thankful for the insightful and astute suggestions from many readers, particularly the three anonymous reviewers from JLAS, Melanee Thomas, Lisa Lambert, Merike Blofield, Christina Xydias, Ito Peng, Patricia Strach, and participants at the 'Mothers and Others' Conference in Banff, Canada in $20 \mathrm{I}$. Susan Franceschet gratefully acknowledges research funding from Canada's Social Sciences and Humanities Research Council for field research in Argentina and Chile. Jennifer M. Piscopo thanks the University of California, San Diego, the Carrie Chapman Catt Center at Iowa State University, Occidental College, and the American Political Science Association's Small Grant Research Program for supporting fieldwork in Argentina and Mexico. Gwynn Thomas thanks the Baldy Center and the Gender Institute both at the University at Buffalo for supporting fieldwork in Chile and Costa Rica. All authors contributed equally to this article. 
in arguments about the political value of the moral sensibilities derived from mothering. Maternalism became the starting point for gender scholars studying women's engagement with politics in the mid-twentieth century. Writing in the early I970s, Elsa Chaney argued that female leaders in Peru and Chile in the I950s and 1960s turned to maternalism to explain and justify their political involvement and priorities. According to Chaney, "women overwhelmingly agreed to a division of labour in the polity that parallels the traditional, unequal roles of men and women in the family'. ' Following Chaney's groundbreaking work, scholars have examined how ideologies and discourses that exalt women's capacity to mother and nurture can either exclude women from the competitive, corrupt world of politics or shape demands for women's political inclusion.

Scholars have coined terms such as supermadre ('super-mother') ${ }^{2}$ or 'militant mothers' 3 to explain how women throughout Latin America have drawn on their caring roles to create spaces for themselves in public life. In the 1970s and I 980 s, activist mothers formed the backbones of human rights movements challenging the extreme abuses of military dictatorships as well as community organisations addressing the socio-economic deprivations created by neoliberal policies. Invocations of maternalism allowed diverse groups of women to build alliances in civil society, even as their ability to both contest and conform to social expectations around motherhood often depended on their positions within societies divided by class, race, ethnicity and location.

More recently, women's use of maternalism coexists with newer discourses of gender equality emerging from the feminist movements and democratic transitions that swept the region in the 1980 s and I990s. Organised women demanded that governments in the newly democratised countries create more equitable access to positions of political power. These demands have been partly met: women now hold nearly 40 per cent of legislative offices in some Latin American countries; they have been credible contenders for or captured the presidencies of the region's most prominent countries; and they have led high-profile ministries and attained seats on constitutional and supreme courts. Thus, the social and political context in which women seek entry into politics has greatly changed from the one confronted previously by the 'supermadres' or 'militant mothers'. These changes imply a need to reevaluate the role of maternalism by asking how it shapes women's political participation in the contemporary era.

${ }^{1}$ Elsa Chaney, Supermadre: Women in Politics in Latin America (Austin, TX: University of Texas Press, 1979) p. 2 I.

${ }^{2}$ Initially coined by Chaney, Supermadre.

3 Articulated by Sonia Alvarez, Engendering Democracy in Brazil (Princeton, NJ: Princeton University Press, 1990). 
In this article, we argue that discourses of maternalism condition women's involvement in electoral politics in two ways: first, in the gendered division of household labour that creates structural barriers to women's political careers, and second, in the strategic frames available to female politicians seeking to legitimate their public roles and advance their policy preferences. Consequently, we find both continuity and change in the intersection of motherhood and politics. In terms of structural barriers, maternalism emphasises the values of nurturing and selflessness in public life while reinforcing the greater care demands faced by women in the private realm. In terms of strategic framing, maternalism remains a powerful cultural resource for women. While female politicians are no longer exclusively seen (by themselves or by society) as militant mothers or supermadres, their self-presentation is still influenced by cultural narratives of gender differences that are centred in maternal ideals. Maternalism's emphasis on caretaking, compassion and domestic management still shapes the public's response to female political leaders. We argue that maternalism's enduring power means that today's female politicians, irrespective of their individual experience or identities, often frame their office-holding ambitions and their policy preferences in culturally acceptable, gendered terms.

Female politicians draw on maternalism strategically, yet not always uniformly. Democratisation's gender equality discourses also offer women ways to ground their political participation: women can run for office not because their maternal sensibilities are needed, but because they are equal citizens. Indeed, the strikingly varied responses of today's female politicians to maternalism indicate that while traditional gender roles remain influential, gender equality discourses allow women to construct political identities beyond those of wife or mother. To illustrate this complexity, we develop a typology that captures four cultural frames that female politicians in Latin America strategically employ:

I) Traditional supermadre: wherein women present motherhood as central to their political identity and concerns;

2) Technocratic caretaker: wherein women emphasise their professional credentials over their maternal identity, though their technocratic skills are frequently tied to expertise in social issues related to caretaking;

3) Macho minimiser: wherein women perceive a need to soften their aggressive image with cultivated appeals to femininity; and

4) Difference denier: wherein women deny that gender inequality shapes men's and women's political opportunities, dismissing claims of sexism in politics.

These categories capture the varied ways that female politicians deploy and contest maternalism as they negotiate the intersection of modern political 
careers and traditional gender roles. Importantly, these categories are rooted in norms about ideal gender roles, norms shaped implicitly in relation to middleand upper-class women from dominant racial and ethnic groups. These categories do not capture the personal identity or unique individuality of any single woman; rather, they catalogue a 'toolbox' of cultural frames that female politicians use to legitimise their presence in particular political contexts. We argue that these categories reveal how women's claims to political power, and their relationship with women's interests, capture maternalism's contemporary complexity: traditional ideals persist despite the spread of democracy's equality norms. This 'toolbox' of cultural frames is fluid rather than static, as equality discourses now compete with evolving maternalist discourses.

Our categories are derived inductively, drawn from an analysis of female politicians' presidential campaigns as well as from extensive interviews with female politicians competing for national level office. Together, we have data from 80 interviews with women politicians, conducted over I6 different trips to Argentina, Chile, Costa Rica and Mexico between 1999 and 2014 . We also conducted original analysis of media coverage and campaign imagery in the presidential campaigns in Chile (2005-6), Argentina (2007) and Costa Rica (2010), which included field interviews with journalists and campaign strategists. As such, our research allows us to analyse patterns of maternalist and democratic discourses across a wide array of sources. Importantly, these political women are almost exclusively drawn from elite, well educated, middle- to-upper income groups. Most also come from their country's dominant ethnic or racial group. Yet, when deployed at the national level, cultural frames influence the strategies available to diverse groups of women participating at all levels of politics. Our qualitative data is thus situated within the broader context of contemporary democratic Latin America.

We begin by discussing the historical origins of maternalism in Latin America, showing how maternal identities historically provided the cultural narratives that legitimated women's public roles. Next, we use secondary public opinion and survey data, and primary interview data, to argue that, in the democratic era, cultural expectations still shape structural barriers that limit women's access to and advancement within politics. We show how the gendered division of household labour impacts the cultural frames available to female politicians, who must strategically deploy narratives of mothering and care. Yet political and social changes also offer women narratives that stress equality. Our analysis leverages data from field interviews and campaign imagery to demonstrate how the ongoing legacy of maternalism mixes with the growing ascendancy of equality discourses. In sum, we show that scholars cannot ignore maternalism's enduring legacy in shaping Latin American women's political participation. 


\section{From Colonialism to Democratisation: Maternalism in Latin America}

Scholarly interest in the intersection of maternalism and women's political participation in Latin America began with Elsa Chaney's work in the I 970 s, and flourished in analyses of women's participation in protests, social movements, guerrilla movements, and democratisation. Scholars drew on Latin America's social and cultural foundations to argue that maternalism informed both how women gained access to political life and how political leaders viewed, accommodated, or resisted women's place in the body politic. Evidence from the democratic era also reveals maternalism's legacy in defining idealised public and private spheres and, consequently, women's and men's appropriate gender roles.

\section{Historical Legacies}

Latin American societies have been indelibly marked by a colonial order that created, maintained and justified unequal power relations through interconnected hierarchies of gender, race, class, geographic location and generation. The colonial political order was founded on patriarchalism, an ideology that justified monarchical rule by appealing to both the divine and natural order of the patriarchal family. The political power of patriarchalism thus depended on everyday practices that naturalised hierarchies of gender (men over women, and male household heads over other members), generation (parents over children), class (elites over lower classes, and elite men over lower-class men and slaves) and race (people of European descent over other races). ${ }^{4}$ As colonial society developed, women's lives were also increasingly governed by the concept of honour, which created linkages among family prestige, the sexual conduct of women, and the purity of European blood. Colonial records reveal how these cultural discourses served as resources in political battles over patriarchal privilege and family status. For example, non-elite men presented themselves as husbands and fathers, drawing on patriarchal discourses to demand political respect. 5 Elite women defended their honour by demanding that courts punish men for breaking marriage promises and legitimise children born out of wedlock. ${ }^{6}$ Both slave and free plebeian women leveraged

${ }^{4}$ Steve Stern, The Secret History of Gender: Women, Men and Power in Late Colonial Mexico (Chapel Hill, NC: University of North Carolina Press, 1995).

s Sarah Chambers, From Subjects to Citizens: Honor, Gender, and Politics in Arequipa, Peru, 1780-1854 (University Park, PA: Pennsylvania State University Press, 1999).

${ }^{6}$ Lyman L. Johnson and Sonya Lipsett-Rivera, The Faces of Honor: Sex, Shame, and Violence in Colonial Latin America (Albuquerque, NM: University of New Mexico Press, 1998); Patricia Seed, To Love, Honor, and Obey in Colonial Mexico: Conflicts over Marriage Choice, I574I87I (Stanford, CA: Stanford University Press, 1988); and Ann Twinam, Public Lives, Private Secrets: Gender, Honor, Sexuality, and Illegitimacy in Colonial Spanish America (Stanford, CA: Stanford University Press, 1999). 
notions of honour in attempts to protect themselves from exploitation and violence. ${ }^{7}$

As newly independent republics replaced Spanish colonial rule, men of all social and racial classes faced expanded political opportunities while women continued to face limitations imposed by patriarchy and honour. Increasingly, legitimate political authority was located not in the natural order of the family or divine design, but as emerging from the consent of politically equal elite men. ${ }^{8}$ A monarch's control over adult, propertied men was increasingly seen as a violation of men's rights to equality and liberty, but men's control over women, children and other household dependents remained just and natural. However, men from working-class, poor and indigenous backgrounds successfully expanded their political power by claiming recognition - and thus political equality - through the patriarchal privileges they shared with elite men.9

By contrast, Latin America's liberal republics initially preserved and reinforced women's lack of political power. Legal codes increased the patriarchal privileges of husbands over their wives and decreased women's rights over property and children. ${ }^{10}$ The liberal republics of the 1800 s actually strengthened the centrality of women's mothering identity within politics. As feminist critics have signalled, liberal republics were built on the political fiction of separate spheres, dividing the legal, public equality of men from the natural, private inequality of women. ${ }^{I I}$ Since contestations over political power unfold in public, politics became the 'natural' preserve of men, an unwholesome area marked by the masculine pursuits of competition, aggression and dominance. The private realm, in contrast, was a feminised space, one associated with women's roles as mothers and wives and idealised as nurturing, restorative and wholesome.

Liberal republics' gendered construction of the public and the private became an enduring legacy of women's political participation in Latin America. Women were formally denied public roles as citizens, but they

7 Sandra Lauderdale Graham, 'Honor among Slaves', in Lyman L. Johnson and Sonya LipsettRivera (eds.), The Faces of Honor: Sex, Shame, and Violence in Colonial Latin America (Albuquerque, NM: University of New Mexico Press, I998), pp. $20 \mathrm{I}-28$.

8 Elizabeth Dore, 'One Step Forward, Two Steps Back: Gender and the State in the Long Nineteenth Century', in Elizabeth Dore and Maxine Molyneux (eds.), Hidden Histories of Gender and the State in Latin America (Durham, NC: Duke University Press, 2000), pp. 3-32.

9 Florencia Mallon, Peasant and Nation: The Making of Postcolonial Mexico and Peru (Berkeley, CA: University of California Press, 1995).

10 Dore, 'One Step Forward'; Elizabeth Dore, 'Property, Household, and the Public Regulation of Domestic Life: Diriomo, Nicaragua, 1840-1900', in Dore et al., Hidden Histories, pp. I47-7I; Donna J. Guy, 'Parents Before the Tribunals: The Legal Construction of Patriarchy in Argentina', in Dore et al., Hidden Histories, pp. 172-93.

${ }^{11}$ Carole Pateman, The Sexual Contract (Stanford, CA: Stanford University Press, 1988). 
resisted by using their private identities as mothers to justify their demands for inclusion and resources. The first wave of the women's movement in Latin America strategically deployed a language of 'civic maternalism' and family welfare to argue for wide-ranging improvements to women's political, legal, economic and social positions. Middle-class and elite women leaders constructed women as the bearers of future citizens and the transmitters of national values ('republican motherhood'). For example, reformers seeking women's suffrage argued that women's expanded political and social participation would ensure healthy families, transmit civic values to future generations, and generally contribute to national stability and progress. ${ }^{12}$ Consequently, public policies on population growth, public health, labour rights, social welfare, and economic development reflected and reinforced a maternalist gender ideology that valorised motherhood and family caretaking. ${ }^{13}$ Reformers demanded the creation and expansion of state programmes to protect women not as citizens, but as mothers. Chile's first protective labour legislation, for instance, benefited working mothers. ${ }^{14}$

Yet even in this period, maternalist discourses contained tensions and contradictions. While motherhood as a cultural resource crossed social divides, lower-class and racially marginalised women often struggled to be recognised as good mothers and citizens. Economic changes in the early twentieth century increased women's labour force participation, yet political and social reformers depicted waged work as masculine and valorised women's roles as homemakers. ${ }^{\text {is }}$ By mid-century, many Latin American states sought to address the twin threats of communism and class conflict through statebuilding projects that brought workers, peasants and urban sectors into the nation. Yet ideals of social harmony still championed the well-ordered family, maintained by a nurturing mother. ${ }^{16}$ On the one hand, the laws and

12 Asunción Lavrin, Women, Feminism, and Social Change in Argentina, Chile and Uruguay, 1890-1949 (Lincoln, NE: University of Nebraska Press, I995); Maxine Molyneux, 'Gender and Twentieth Century State Formation in Latin America', in Dore et al., Hidden Histories, pp. 33-84.

${ }^{13}$ Jadwiga E. Pieper Mooney, The Politics of Motherhood: Maternity and Women's Rights in Twentieth-Century Chile (Pittsburgh, PA: University of Pittsburgh Press, 2009); Karin A. Rosemblatt, Gendered Compromises: Political Cultures and the State in Chile, 1920-1950 (Chapel Hill, NC: University of North Carolina Press, 2000); Molyneux, 'Gender and Twentieth-Century'.

${ }^{14}$ Elizabeth Quay Hutchison, Labor Appropriate to Their Sex: Gender, Labor, and Politics in Urban Chile, 1900-1930 (Durham, NC: Duke University Press, 2001).

is Barbara Weinstein, 'Unskilled Worker, Skilled Housewife: Constructing the Working-Class Woman in São Paulo, Brazil', in John D. French and Daniel James (eds.), The Gendered Worlds of Latin American Women Workers: From Household and Factory to the Union Hall and Ballot Box (Durham, NC: Duke University Press, 1997), pp. 72-99; Rosemblatt, Gendered Compromises.

${ }^{16}$ Heidi Tinsman, Partners in Conflict: The Politics of Gender, Sexuality, and Labor in the Chilean Agrarian Reform, 1950-1973 (Durham, NC: Duke University Press, 2002). 
policies that promoted 'traditional family values' provided political and material support to poor families; on the other hand, these programmes maintained 'notions of female dependency, service, and subordination'. ${ }^{17}$ Populism and corporatism thus perpetuated the centrality of maternal roles for all women while preserving the distinction between women who could and could not dedicate themselves exclusively to these pursuits.

The normative value placed on this vision of motherhood and family also had contradictory effects for women in the socialist-inspired regimes that emerged in the mid-twentieth century. Women actively participated in socialist movements throughout the region, even serving as combatants in armed struggles in Cuba (1959) and Nicaragua (1979). Yet socialist governments reinforced traditional gender roles in the family and workplace by promoting policies that improved wages for working-class men and prioritised women's family responsibilities over their economic or public roles. ${ }^{18}$ Even when women did enter politics, the opportunities presented to them by states, and the ambitions and objectives of the women themselves, often emphasised women's caretaking abilities, rather than their contributions as active citizens or resilient workers. The power of maternalism also appeared in the protagonism of right-wing women resisting socialist projects. In Chile, the conservative group Feminine Power saw the policies of Allende's socialist government as attacking women's roles as wives and mothers. They generated alliances across classes to resist Allende's government by drawing on maternal identities. ${ }^{19}$ In Nicaragua, mothers protested against the draft implemented by the FSLN during the US-Contra war. ${ }^{20}$

\section{Dictatorship and Democratisation}

The connection between women's maternal identities and their political activism has been most thoroughly discussed in the context of Latin America's authoritarian regimes and subsequent pro-democracy movements. Beginning in the I 960 s, civilian and military governments brutally curtailed democratic processes: political parties were disbanded, elections controlled or eliminated,

${ }^{17}$ Ibid., pp. 56-7.

${ }^{18}$ Molyneux, 'Gender and Twentieth Century'; Julia Shayne, The Revolution Question: Feminisms in El Salvador, Chile and Cuba (New Brunswick, NJ: Rutgers University Press, 2004).

19 Margaret Power, Right-Wing Women in Chile: Feminine Power and the Struggle against Allende, 1964-1973 (University Park, PA: Pennsylvania State University Press, 2002).

${ }^{20}$ Lorraine Bayard de Volo, Mothers of Heroes and Martyrs: Gender Identity Politics in Nicaragua, 1979-Ig9g (Baltimore, MD: Johns Hopkins University Press, 200I); Karen Kampwirth, 'Women in the Armed Struggles in Nicaragua: Sandinistans and Contras Compared', in Victoria González and Karen Kampwirth (eds.), Radical Women in Latin America: Left and Right (University Park, PA: Pennsylvania State University Press, 200I), pp. 79-1 10. 
opponents tortured, disappeared, and murdered, and public displays of dissent violently silenced. Militarised regimes effectively shut down the public realm, which paradoxically created space for women, who framed their protests as deriving from maternal imperatives. As such, idealised cultural understandings of motherhood legitimated women's political activity. ${ }^{21}$

The 'national security ideology' of the Southern Cone's military dictatorships positioned the army as heroically fighting the communist menace, in order to preserve and protect women and children. ${ }^{22}$ Yet this conflict destroyed the social fabric by disappearing husbands, fathers, sons and daughters. Women thus mobilised to protest human rights abuses, and marched to demand the return of their disappeared family members, framing their actions as a natural extension of their nurturing roles. Faced with economic crisis and state indifference, poor and working-class women established soup kitchens, shopping cooperatives, handicraft collectives and community childcare centres to address the growing impoverishment of their families. Feminist groups analysed the connection between patriarchal politics in the home and in dictatorships. ${ }^{23}$ Across the political spectrum, women leveraged their cultural power by appealing to maternalist ideologies, exposing the immorality and illegitimacy of the military governments. ${ }^{24}$ Scholars have termed these instances of women's mobilisation under dictatorship 'militant motherhood'.25

Maternalist discourses thus legitimated women's public responses to political crises. This framing implied that a return to 'normal' politics would

${ }^{21}$ Patricia M. Chuchryk, 'Subversive Mothers: The Women's Opposition to the Military Regime in Chile', in Sue Ellen Charlton, Jana Everett and Kathleen Staudt (eds.), Women, the State, and Development (Albany, NY: State University of New York Press, 1989), pp. 130-5 I; Marysa Navarro, 'The Personal is Political: Las Madres de la Plaza de Mayo', in Susan Eckstein (ed.), Power and Popular Protest: Latin American Social Movements (Berkeley, CA: University of California Press, 1989), pp. 241-58.

${ }_{22}$ Power, Right-Wing Women; David Pion-Berlin and George Lopez, 'Of Victims and Executioners: Argentine State Terror, 1975-1979', International Studies Quarterly, 35: March (1991), pp. 63-86; Ximena Bunster, 'Watch Out for the Little Nazi Man That All of Us Have Inside', Women's Studies Quarterly, I I: Summer (1988), pp. 485-9 I.

${ }^{23}$ Alvarez, Engendering Democracy; Lisa Baldez, Why Women Protest: Women's Movements in Chile (Cambridge: Cambridge University Press, 2003); Michelle Bonner, Sustaining Human Rights: Women and Argentine Human Rights Organizations (University Park, PA: Pennsylvania State University Press, 2007); Susan Franceschet, Women and Politics in Chile (Boulder, CO: Lynne Rienner, 2005).

${ }^{24}$ Diana Taylor, Disappearing Acts: Spectacles of Gender and Nationalism in Argentina's 'Dirty War' (Durham, NC: Duke University Press, 1997); Gwynn Thomas, Contesting Legitimacy in Chile: Familial Ideals, Citizenship, and Political Struggle, 1970-I9go (University Park, PA: Pennsylvania State University Press, 201 I).

${ }^{25}$ This was the termed used by Alvarez, in Engendering Democracy. For similar arguments, see Jaquette, Women's Movement; Baldez, Why Women Protest; Sallie Westwood and Sarah A. Radcliffe (eds.), Viva: Women and Popular Protest in Latin America (New York: Routledge, 1993). 
allow women to return to the private sphere and their apolitical roles as mothers, while men could assume their rightful place as political leaders. ${ }^{26}$ Despite women's notable participation during this era, the masculine norms and expectations associated with electoral politics did re-emerge as democratisation began. Men reclaimed their leadership roles: in the founding democratic elections, women attained, on average, 6 per cent of legislative seats. ${ }^{27}$ Many Latin American women continued their activism at the grassroots and popular levels; ${ }^{28}$ however, those seeking entrance into the rarefied world of national office confronted anew the historical legacies of maternalism.

\section{Maternalism and Electoral Democracy}

Democratisation did, however, coincide with alternative discourses that were developing simultaneously in the transnational and international arenas: those of gender equality and human rights. The United Nations Decade for Women (1975-85) triggered regional and international collaborative efforts to have women's rights recognised as basic human rights. Eager to demonstrate their democratic credentials, Latin America's newly elected leaders signed the UN Convention on the Elimination of All Forms of Discrimination against Women (CEDAW), committing their governments to a range of gender equality reforms. Subsequent regional developments, such as the creation of the Inter-American Court on Human Rights and, more notably, the adoption of the Inter-American Convention on the Prevention, Punishment, and Eradication of Violence against Women, further enhanced the salience of women's rights and gender equality discourses throughout the region. ${ }^{29}$ Transnational networks and feminist encuentros continued to bring gender equality advocates together to press for the social and political changes that enhance women's wellbeing and autonomy. ${ }^{30}$

In particular, gender equality advocates leveraged two major policy concessions designed specifically to combat women's marginalisation from formal politics following democratisation. ${ }^{31}$ First, in keeping with their obligations

${ }^{26}$ Franceschet, Women and Politics; Baldez, Why Women Protest.

${ }^{27}$ Magda Hinojosa, Selecting Women, Electing Women: Political Representation and Candidate Selection in Latin America (Philadelphia, PA: Temple University Press, 2012), p. 4.

${ }^{28}$ Jane Jaquette (ed.), Feminist Agendas and Democracy in Latin America (Durham, NC: Duke University Press, 2009), Nathalie Lebon and Elizabeth Maier (eds.), Women's Activism in Latin America and the Caribbean (New Brunswick, NJ: Rutgers University Press, 2010).

${ }^{29}$ Elisabeth Jay Friedman, 'Re(gion)alizing Women's Human Rights in Latin America', Politics \& Gender, 5 (2009), pp. 349-75.

${ }^{30}$ Sonia E. Alvarez, 'Translating the Global Effects of Transnational Organizing on Local Feminist Discourses in Latin America', Meridians, r: I (2000), pp. 29-67.

${ }^{31}$ Jennifer Piscopo and Gwynn Thomas, 'Challenging Gender Inequality within the State: Policy Agencies and Quota Laws in Latin America', preprint, 2014. 
under CEDAW, new democratic governments created women's policy machineries in the executive branch, tasking these agencies with promoting gender equality in public policy and administration. Second, many Latin American legislatures passed electoral quota laws, which required political parties to nominate specified percentages of women to public office. ${ }^{32}$ Although their impact has varied throughout the region, scholars concur that quotas remain the most effective method of boosting women's numerical representation in the short run. Proponents view quota laws, even weak ones, as necessary for combating women's political exclusion and promoting gender equality. ${ }^{33}$

Latin American governments now include more women, marking a notable shift from the i 990 s. Due largely to electoral quota laws, by October 2014, women's share of legislative seats rose to 25.6 per cent of the region's single or lower chambers, placing Latin America second only to the Nordic countries (4r.6 per cent) and on par with Western Europe. In Bolivia, Cuba, Nicaragua and Ecuador, women's representation exceeds 40 per cent, and in Costa Rica, Argentina and Mexico, it exceeds 30 per cent. ${ }^{34}$ Change has also appeared in the executive branch, where women have attained (and been re-elected to) the presidencies of the region's most powerful and most developed countries, including Chile (Michelle Bachelet, 2006 and 2013), Argentina (Cristina Fernández de Kirchner, 2007 and 20 I I); Costa Rica (Laura Chinchilla, 20 I0); and Brazil (Dilma Rouseff, 2010 and 2014). Women have also been credible presidential candidates in Mexico, Venezuela and Peru.

Yet maternalism's legacies remain. Recent studies echo Chaney's findings from nearly a half-century ago: Latin American legislatures and executives are characterised by divisions of policy labour according to traditional ideas about men and women's prescribed social roles. Schwindt-Bayer finds that female legislators across the region place higher priorities on issues related to children and families and Miguel argues that female legislators in Brazil most commonly support policies that involve caring and caretaking. ${ }^{35}$ Likewise, Escobar-Lemmon and Taylor-Robinson's study of female ministers

32 Mala Htun and Mark Jones, 'Engendering the Right to Participate in Decision Making: Electoral Quotas and Women's Leadership in Latin America', in Nikki Craske and Maxine Molyneux (eds.), Gender and the Politics of Rights and Democracy in Latin America (London: Palgrave, 2002).

33 Htun and Jones, 'Engendering the Right'; Hinojosa, Selecting Women; Drude Dahlerup and Lenita Freidenvall, 'Quotas as a "Fast Track" to Equal Representation', International Feminist Journal of Politics, 7: I (2005), pp. 26-48.

34 'Women in National Parliaments', Inter-Parliamentary Union World Classification. Available at http://www.ipu.org/wmn-e/classif.htm (accessed I6 December 2014).

${ }^{35}$ Luis Felipe Miguel, 'Policy Priorities and Women's Double Bind in Brazil', in Susan Franceschet, Mona Lena Krook and Jennifer M. Piscopo (eds.), The Impact of Gender Quotas (New York: Oxford University Press, 201 2), pp. I03-1 8; Leslie A. Schwindt-Bayer, Political Power and Women's Representation in Latin America (New York: Oxford University Press, 2010). 


\section{2

from 1980 to 2003 concludes that, even as the number of women in presidential cabinets increases, women are concentrated in the feminised, and less prestigious, portfolios, such as those related to culture, tourism and family. ${ }^{36}$

Moreover, female presidents and presidential contenders still confront opportunities and obstacles linked to cultural definitions of appropriate political roles for men and women. Latin America's first elected female presidents, Violeta Chamorro (Nicaragua, 1990-7) and Mireya Moscoso (Panama, 1999-2004), campaigned as widows of powerful male leaders, portraying themselves as mothers of the nation. ${ }^{37}$ Doing so minimised criticisms that they had violated cultural norms of femininity by seeking entry into a traditionally masculine domain. While today's female presidents are less constrained by maternalism, our analysis of media coverage from their campaigns reveals that familial terms often dominate narratives about women's political careers. For example, the media stressed Fernández's status as then-President Néstor Kirchner's wife, neglecting her status as senate leader and powerful player within the Peronist party. While many male politicians also benefit from ties to political families, we find that the popularity and authority of female politicians are often seen as deriving from male household heads rather than being seen as a product of women's own political skills. Positioning powerful political women within familial narratives occurs even when family ties do not exist. For instance, media outlets referred to Rousseff as 'the woman [outgoing president] Lula gave to Brazil' and described outgoing Costa Rican president Óscar Arias as Chinchilla's 'political father'. ${ }^{8}$ Irrespective of individual female politicians' talents or résumés, cultural discourses explaining their ascension to national office reflect deeply seated patriarchal norms.

\section{Motherhood as a Structural Constraint}

While much of the scholarship on maternalism in Latin America has focused on women's entry into politics, less attention has been paid to how motherhood creates unequal structural obligations that constrain women's political careers. In this section, we use survey and interview data to illuminate a central contradiction of maternalism in the era of electoral democracy: the tension between beliefs about gender equality and maternalism. Despite gender equality norms, a gendered division of household labour with

${ }^{36}$ Maria Escobar-Lemmon and Michelle Taylor-Robinson, 'Women Ministers in Latin American Governments: When, Where, and Why?', American Journal of Political Science, 49: 4 (2005), pp. 829-44.

37 Mireya Navarro, 'The Widow of Ex-Leader Wins Race in Panama', The New York Times, 3 May 1999; Karen Kampwirth, 'The Mother of the Nicaraguans: Doña Violeta and the UNO's Gender Agenda', Latin American Perspectives, 23: Winter (1996), pp. 67-86.

${ }^{8}$ Elza Filha and Lennita Ruggi, 'Baton na primeira página', paper presented at the Brazilian Congress of Communication, Recife, 20II; author's personal communication with Rosemary Castro Solano, 26 March 2013. 
women performing the bulk of the caring duties persists. Female politicians in Latin America must choose between attending to their political obligations or attending to their families.

Latinobarómetro data from the 1990 s and 2000 s demonstrate the growing influence of gender equality norms alongside the persistence of maternal ideals. ${ }^{39}$ Survey respondents acknowledge changing norms about family care: for example, 87 per cent of respondents across Latin America affirmed in 2006 that 'domestic work and responsibility for children' should be shared by 'both the mother and father equally'. Results from countries where we conducted our field research were consistent with this average: respondents selected both parents at 87 per cent in Argentina, 90 per cent in Chile, 92 per cent in Costa Rica and 8I per cent in Mexico. However, respondents express greater ambivalence when asked direct questions about women's work outside the home. When prompted with the statement, 'It is better for women to remain at home and for men to work', agreement across Latin American countries ranged from 25 per cent to 60 per cent in both 1997 and 2009, with an average agreement of 36 per cent in 1997 and 38 per cent in 2009. Table I shows that our four countries of study again reflect regional trends: twothirds of respondents disagreed, believing that women should work outside the home. Yet when asked whether 'Women should only work if men do not earn enough', respondents disagreed less, indicating greater agreement that women should only work when forced by economic necessity.

Results from the World Values Survey (WVS), conducted in 2006 in Argentina and Chile, 2005 in Mexico, and 2008 in Costa Rica, also demonstrate the continued value placed on traditional gendered divisions of work and care. When reacting to the statement, 'When jobs are scarce, men should have more right to a job than women', one-quarter to one-third of all respondents agreed. Another statement, 'A job is great but being a housewife is just as fulfilling', asks respondents whether women can find equal value in either paid employment or unpaid domestic work. In response, 74 per cent of Mexicans, and 77 per cent of Mexican women, agreed. In Argentina, 65 per cent of respondents (and 60 per cent of female respondents) agreed, and in Chile, 56 per cent of respondents (and 52 per cent of female respondents) agreed. $4^{\circ}$ Though the WVS cannot pinpoint the ideological orientations underlying such attitudes, the responses reveal how women's caretaking work is valued: a significant portion of citizens believe that men are more

39 Latinobarometer (http://www.latinobarometro.org) and World Values Survey (www. worldvaluessurvey.org) data can be accessed on-line. Neither survey consistently asks the same questions, limiting over-time comparisons.

40 The concrete employment opportunities may explain inter-country variations, as countries with higher levels of development (i.e. Argentina and Chile) may offer women more attractive work opportunities. 


\section{4 Franceschet, Piscopo and Thomas}

Table I. Attitudes towards Gender and Family Roles in Latin America

Better for Women to Stay at Home: Per cent of Respondents Choosing Disagree or Strongly Disagree

\begin{tabular}{lccccccc} 
& \multicolumn{3}{c}{ I997 } & & \multicolumn{3}{c}{2009} \\
\cline { 2 - 3 } Country & Men & Women & Total & & Men & Women & Total \\
Argentina & 61.2 & 70.5 & 66.2 & & 66 & 73.5 & 70 \\
Chile & 71.9 & 81.2 & 76.9 & & 68.9 & 79.6 & 74.4 \\
Costa Rica & 45.0 & 51.9 & 48.6 & & 66.6 & 69.0 & 67.8 \\
Mexico & 68.2 & 68.9 & 68.6 & & 61.9 & 69.3 & 65.7
\end{tabular}

Women Should Work Only if Men Do Not Earn Enough: Per cent of Respondents Choosing Disagree and Very Much Disagree: Per cent of Respondents Choosing Disagree or Strongly Disagree

\begin{tabular}{lccc} 
& \multicolumn{3}{c}{2008} \\
\cline { 2 - 4 } Country & Men & Women & Total \\
Argentina & 55.6 & 64.9 & 60.5 \\
Chile & 66.9 & 70.1 & 68.6 \\
Costa Rica & 51.9 & 52.0 & 51.9 \\
Mexico & 52.1 & 51.3 & 51.7
\end{tabular}

Source: Latinobarométro.

entitled to paid employment, and a majority believe that unpaid domestic work and paid labour force participation carry equal emotional benefits for women.

Yet a sex gap does appear in some surveys, with women's views on motherhood diverging more than men's. With the exception of Mexico, women disagreed more than men on both WVS questions: for instance, nearly 35 per cent of Chilean men agreed economic crises entitled men to employment compared to only 26 per cent of Chilean women. The Latinobarometer questions reported in Table I also shows these gaps: in 2009, for example, women in all four countries disagreed more strenuously than men that women should stay at home with the children.

Together, the two surveys reveal several trends. First, despite respondents' positive endorsement of shared parenting, ideals of the male breadwinner and the female housewife retain cultural importance. Second, women appear more willing than men to abandon maternalist ideologies and support women's employment opportunities. Overall, however, maternalism remains central to the cultural imaginary in Latin America and attitudes towards women's possible abandonment of traditional roles remain highly ambivalent. Gender equality ideals and gender role differentiation are coexisting, often uneasily.

\section{The Caretaking Gap}

This uneasy coexistence translates into very practical limitations for careerminded women, as revealed by several time use surveys. A 2007 survey in 
Argentina, for example, estimated that 80 per cent of all unpaid work is performed by women, where 'unpaid' work refers to in-home domestic chores, including those associated with childrearing. ${ }^{41}$ Similarly, a 2003 study in Montevideo concluded that women were the principal caregivers in 90 per cent of homes with children. ${ }^{42}$

More specifically, the Montevideo survey estimated that households with school-aged children require 48 hours per week of childcare, with women doing disproportionately more than men: 32 hours $(67$ per cent) compared to 16 hours ( 33 per cent). ${ }^{43}$ In Mexico, a 2010 survey found a pronounced sex gap for an average home requiring 36 hours of unpaid domestic labour: women completed 30 hours, while men completed 6 ( 17 per cent). CEPAL, using recent data from Colombia, Mexico, Peru and Uruguay, found that women spent about one-half to one-third of the time men spent on paid employment, but three to five times more time than men on unpaid domestic work. ${ }^{44}$ Moreover, men's portion of unpaid work, when it occurs, differs significantly from women's: female survey respondents report cooking, washing clothes and dishes, cleaning and shopping, while male respondents report repairing or installing household appliances. ${ }^{45}$ The caretaking gap, a measurement comparing the time men and women devote to childcare, is significantly higher across Latin America than in the global North: for instance, CEPAL calculates that the gap averages 43 minutes per day in Mexico and Nicaragua, and but between 14 and 20 minutes per day in countries such as France, Finland, the United States, and the United Kingdom. ${ }^{46}$

These trends have clear implications for women seeking political careers. First, class matters: while many surveys do not disaggregate their data, those that do reveal clear differences across income quintiles. While the caregiving gap never disappears, it is smallest among men and women in the highest quintile. This narrowing does not mean, however, that upper-class men undertake more domestic chores. ${ }^{47}$ Rather, upper-class men perform the same number of chores as lower-class men, and the fewer chores performed by upper-class women relative to lower-class women indicate that upper-class women outsource their unpaid work to paid domestic help or other family members,

${ }^{41}$ Natalia Martínez, La equidad en el empleo: el caso de Argentina (Córdoba, Argentina: CISCSA, 2007), p. 20.

42 Rosario Aguirre 'Los cuidados familiares como problema público y objeto de políticas', in Irma Arriagada (ed.), Familias y politicas públicas en América Latina: una historia de desencuentros (Santiago: CEPAL, 2007), p. 193.

${ }^{43}$ Ibid., pp. 192-3.

${ }^{44}$ CEPAL, Social Panorama of Latin America (Santiago: CEPAL, 201 2 ) p. 123.

${ }^{45}$ Martínez, La equidad; ELA, Equipo Latinoamericano de Justicia y Género, 'Situación y percepción de las mujeres Argentinas acerca de su condiciónes de vida' (Buenos Aires: 2006).

${ }^{46}$ CEPAL, Panorama Social (Santiago: CEPAL, 2009), p. 176.

47 CEPAL, Panorama Social (2009), p. 176; (2012), p. I 23. 
usually also women..$^{8}$ Consequently, economically elite women will face lower structural barriers to pursuing careers, including those in politics. The class difference in the caretaking gap provides one reason why female politicians at the national level are disproportionately elite. ${ }^{49}$

Second, family size conditions women's political opportunities. The fewer children women have, the more women are able to pursue careers outside the home. ${ }^{\circ}$ A 2005 survey in Argentina found, for instance, that nearly 69 per cent of women with no children work outside the home, compared to nearly 60 per cent of women with one child, 5 I per cent of women with two children, and only 37 per cent of women with three or more children. ${ }^{5}$ These trends echo the relationship between family size and women's political engagement. For example, another Argentine survey showed that 67 per cent of women who live alone, compared with 50 per cent of women who live with a partner and children, expressed interest in politics. Further, 23 per cent of women who live alone participate in political, civic or labour organisations, compared to ro per cent of women who live with spouses and children. ${ }^{52}$ Women without children have more time to learn about, and participate in, politics.

That the caretaking gap constrains women's political careers has also been supported by studies comparing male and female politicians' career pathways. In Costa Rica, Colombia and Argentina, female legislators are less likely to be married and have fewer children when compared to male legislators. 53 Our own data from all legislators elected to the Argentine Chamber of Deputies and Senate from 1999 to 2009 underscore these findings. We find no meaningful sex difference in ages; most legislators are in their $40 s$ and 5os, but

${ }^{48}$ Merike Blofield, Care Work and Class: Domestic Worker's Struggle for Equal Rights in Latin America (University Park, PA: Pennsylvania State University Press, 20 I2); Débora Lopreite, 'Gendering Welfare State Regimes in Latin America: Argentina in Comparative Perspective', in Jordi Díez and Susan Franceschet (eds.), Comparative Public Policy in Latin America (Toronto: University of Toronto Press, 2012), pp. 228-46.

49 Susan Franceschet and Jennifer M. Piscopo, 'Gender and Political Backgrounds in Argentina', in Krook et al. (eds.), The Impact of Gender Quotas, pp. 43-56; Franceschet, Women and Politics.

so CEPAL (2009), pp. $176-8$.

51 Martínez, La equidad, p. 2 I.

${ }^{52}$ ELA, pp. 58-60.

53 Michelle A. Saint-Germain, 'Paths to Power of Women Legislators in Costa Rica and Nicaragua', Women's Studies International Forum, 16: 2 (1993), pp. I19-38; Leslie Schwindt-Bayer, 'Women Who Win: Social Backgrounds, Paths to Power, and Political Ambition in Latin America', Politics \& Gender, 7: I (201 I), pp. I-33. Patterns in Latin America generally match findings of studies elsewhere. See, for example, Jerome H. Black and Lynda Erickson, 'Similarity, Compensation, or Difference? A Comparison of Female and Male Office-Seekers', Women and Politics, 21: 4 (2000), pp. I-38; and Debra L. Dodson, 'Change and Continuity in the Relationship between Private Responsibility and Public Officeholding: The More Things Change, the More They Stay the Same', Policy Studies Journal, 25 (1997), pp. 569-84. 
we find significant sex differences in family status. In both chambers, women are more likely to be divorced, single or widowed when compared to men. Only 55 per cent of female deputies are married, compared to 80 per cent of male deputies, and only 66 per cent of female senators are married, compared to 85 per cent of male senators. Nearly twice as many female senators are divorced or single when compared to male senators. ${ }^{54}$

Likewise, male representatives have more children than female representatives. Ninety-six per cent of male deputies and 99 per cent of male senators have children, compared to only 86 per cent of female deputies and 93 per cent of female senators. 55 Female representatives also have smaller families: in the Argentine chamber; most women have either one or two children (43 per cent), whereas most men have anywhere from three to seven children (6 I per cent). In the Argentine Senate, most men and most women have anywhere from three to seven children; however, more male senators ( 66 per cent) have large families when compared to female senators ( 53 per cent). ${ }^{6}$ These results give empirical weight to the conclusion that female officeholders face greater difficulties in reconciling work and family life.

Also compelling are data from the 1997 and 2006 waves of the Latinobarometer, which asked: 'Do you believe that women and men have the same chances to attain public office?' While the question did not specifically reference the caretaking gap, the aggregate results, reported in Figure I, indicate region-wide scepticism about women's equal access to political life. In Argentina, Chile and Mexico, in 2006, half or nearly half of all respondents answered 'no', and female respondents (not shown in the figure) answered 'no' by seven or eight percentage points more than male respondents. Further, in all cases save Chile, El Salvador and Panama, the percentage of all respondents, and the percentage of female respondents, answering 'no' increased from 1997 to 2006 . This outcome indicates that neither equality policies (i.e. gender quotas) nor concrete increases in women's representation have persuaded Latin American citizens that politics is an even playing field. In fact, scepticism about equal access to politics has increased. This finding may reflect various preoccupations among respondents, but it is possible that as government rhetoric about gender equality leads more women to pursue high-level political offices, more women encounter the structural barriers imposed by motherhood.

54 The differences are statistically significant in a chi-squared test at the I and 5 per cent levels, respectively.

s5 The difference is statistically significant in a chi-squared test at the I per cent level in both cases.

56 The differences in family size are statistically significant in a chi-squared test for the chamber (at the I per cent level) and not the senate. The absence of statistical significance in the senate, however, may be due to the small sample size. 
Figure I. Women and Men Have the Same Chances to Attain Public Office: Per cent of Male and Female Respondents Answering 'No'

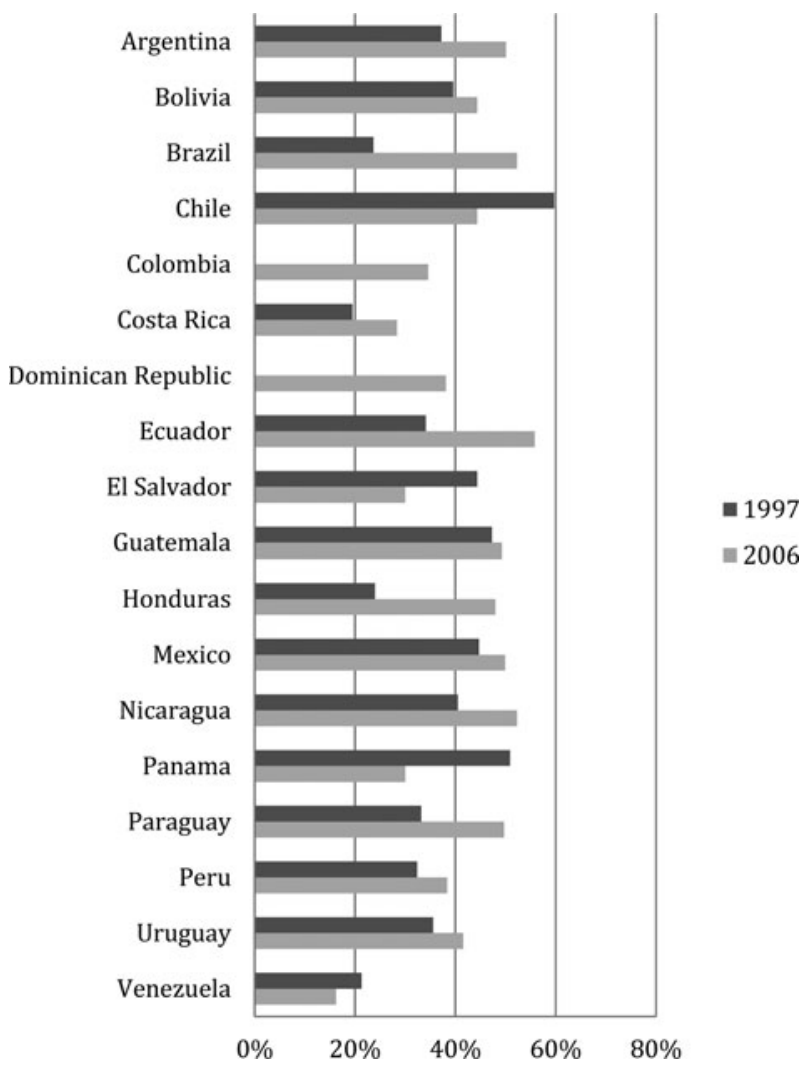

Source: Latinobarométro.

\section{Experiencing Difficulties First-hand}

Indeed, female politicians across the political spectrum describe the structural constraints associated with motherhood. An overwhelming number of women interviewed noted that their careers could not have advanced without supportive husbands and families, and, most importantly, without other women performing domestic work. A well-known Argentine leader noted that 'behind every female politician is a chain of women doing domestic work'. ${ }^{57}$ Her contemporary from a left-wing Mexican party reported that 'the support of her family and husband has been key'. ${ }^{8}$ In Argentina, a young legislator described relying on her mother and extended family to provide childcare during the

57 Author interview, Argentina, 22 Aug. 2014.

58 Author interview, Mexico, Is Dec. 2009, \# I. 
congressional term. ${ }^{59}$ A number of Chilean politicians credited their nannies and their own mothers in helping them reconcile family roles with their political careers. ${ }^{60}$

Women also highlight how the caretaking gap limits their access to and advancement in political office. A long-time Mexican politician stated succinctly, 'The double day still exists'. ${ }^{61}$ An Argentine deputy said that women are 'limited by the time they must spend on housework and reproductive work, and these tasks limit the time that women can dedicate to political participation; we must spread the idea that the world of women has other possibilities'. ${ }^{62}$ Her colleague from the socialist party similarly lamented these social and cultural restrictions: 'We've arrived at the ceiling: women still have domestic responsibilities, and this will limit their political possibilities'. ${ }^{63} \mathrm{~A}$ Chilean deputy echoed this sentiment, saying, "we [women] are in the public world, but with a heavy backpack that says "domestic work" on our back, and that makes our careers go very slowly'. ${ }^{64}$

Related, nearly all interviewees mentioned the difficulties posed by political schedules: parliamentary sessions and plenary debates often last all night, and evenings and weekends fill with meetings and events. This hectic pace assumes either the absence of domestic obligations or the presence of other caretakers. Two Chilean politicians independently lamented evening meetings, with one reflecting, 'The logic of the [men] is always after 6 o'clock and our [the women's] logic is to see if a lunch or breakfast meeting is possible so as not to complicate our [other] work'. ${ }^{65}$ An Argentine deputy shared this frustration, recalling, 'I tried to convince them to change the hours of the meetings and they stopped respecting me ... In the end, I had to tell them that I might not always be there'. Yet she added that her situation was uncommon, 'because there are very few women in the chamber with young children'. ${ }^{66}$ One legislator summarised the difficulties: 'The schedules, the places where the meetings are, the hours - they are all sexist!' ${ }^{67}$

An Argentine senator speculated that men prefer strategy meetings scheduled for the evening, because they know women cannot attend. In her view, men wish 'to exclude women from the agenda-setting meetings, but include them later on in the working sessions where the [already made] plans are edited and finalised ... When there's discussion of a document, it's generally

59 Author interview, Argentina, 23 April 2009.

60 Author interviews, Chile, I 8 Aug. 1999; 25 Aug. 1999; and 29 July 2002.

${ }^{61}$ Author interview, Mexico, is Dec. 2009, \#2.

${ }_{62}$ Author interview, Argentina, 7 April 2009.

${ }_{63}$ Author interview, Argentina, 15 April 2009.

${ }^{64}$ Author interview, Chile, 2 Nov. 1999.

${ }_{65}$ Author interviews, Chile, 8 Aug. and 20 Aug. 1999.

${ }^{66}$ Author interview, Argentina, 9 May 2009.

${ }^{67}$ Author interview, Argentina, 22 Aug. 2014. 
a document that's already been elaborated'. ${ }^{68}$ A deputy lamented that, 'the congress demands so much of women, as if they don't have any other responsibilities; well, the men do not actually have other responsibilities ... [and] they use the task of childcare against women, arguing that it means women cannot participate in the most important discussions'. ${ }^{69}$ Keiko Fujimori, Peru's presidential candidate in 2012, encountered this no-win situation: Fujimori took maternity leave twice while serving in congress, leading opposing candidates to claim she lacked sufficient experience in and commitment to governing. ${ }^{\circ 0}$ Thus, the sexual division of labour limits women's availability for political operations, curtailing women's ability to climb party hierarchies and assuring men's political dominance.

Further compounding this problem is travel. Many interviewees underscored the difficulties in travelling between the capital and their home district, a burden particularly acute for mothers. ${ }^{71}$ In Chile, the majority of the population lives in Santiago, but the national congress is located in Valparaíso, I 30 kilometres away. In Argentina, deputies and senators spend half the week in the capital, Buenos Aires, and half the week in their home province. Thus, many legislators face the challenges of maintaining a household in two cities. Not surprisingly, politically active women in both countries routinely cite the enormous challenges of reconciling political careers with family life. In Chile, which had no gender quota, interviewees frequently cited this difficulty to explain women's under-representation in congress.

In sum, cultural beliefs translate into concrete realities that limit women's availability for public service. Female politicians who are both mothers and professionals confront a paradox: conforming to traditional roles means prioritising families and thus violating the norms that govern the everyday business of politics, but dedicating oneself fully to their careers violates maternal expectations. Either way, political women must transgress the cultural norms of motherhood, and political competitors or opponents can exploit any missteps. The cultural expectations placed on women to care for families create an even higher barrier for non-elite women who often have fewer personal and family resources to navigate political careers. Elite women dominate both elected and non-elected national office. Non-elite women, including indigenous or African-origin women, have made inroads into national politics, yet progress remains slow: for example, in the countries where indigenous women have

68 Author interview, Argentina, 6 Sept. 2006.

69 Author interview, Argentina, 7 April 2009.

70 Author communication with Beatriz Llanos, 24 July 2012.

${ }^{71}$ Author interviews, Argentina, 23 April and 29 April 2009. 
made the most gains, Bolivia and Ecuador, they remain less than 4 per cent of the legislature. $7^{2}$

\section{Motherhood as Frame for Political Action}

Given that motherhood still constrains women's political participation, what role does the ideology of maternalism play in politics in the contemporary period? Do individual women still act as Chaney's supermadres, framing their political careers by appealing to mothering roles? Or do emerging norms of gender equality provide alternative discourses through which women justify their entry into politics? To answer these questions, we examined the political campaigns of Latin America's female presidential candidates, both in terms of media coverage and the candidates' self-presentation, and the perspectives of female officeholders at the national level. National politics is a site for the production and dissemination of cultural frames that define expectations about the political capacities and leadership qualities of men and women.

We found that women holding office are acutely aware of dominant expectations surrounding their political roles, though their responses vary. ${ }^{73} \mathrm{We}$ identified four principal ways that women use maternalism as a frame for political action: the traditional supermadre, the technocratic caretaker, the difference denier, and the macho minimiser. Like all typologies, these categories represent ideal types. The categories do not lock in the identities of individual female politicians and they do not predominate in certain political parties; rather, they represent an array of cultural narratives that female politicians can deploy depending on particular contexts. For instance, opponents, competitors, and the media may draw on gendered ideals to frame female politicians in certain ways, and female politicians may counter with their own self-presentations. Similarly, the policy issues most important to voters can provide female politicians with opportunities to strategically deploy certain aspects

${ }^{72}$ Mala Htun, Inclusion Without Representation: Gender Quotas and Ethnic Reservations in Latin America (New York: Cambridge University Press, forthcoming), Table 2.3. See also Mala Htun and Juan Pablo Ossa, 'Political Inclusion of Marginalised Groups: Indigenous Reservations and Gender Parity in Bolivia', Politics, Groups, and Identities, I: I (2013), pp. 4-25; The autobiography of Brazilian leader Benedita da Silva provides an in-depth look at the challenges faced by one Afro-Brazilian woman from the working class to craft a political career (Benedita da Silva, Medea Benjamin and Maisa Mendonça, Benedita da Silva: An Afro-Brazilian Woman's Story of Politics and Love (Oakland, CA: Food First Books, 1997).

${ }^{73}$ While we focus on maternalism and women's political participation, we should note that paternalism may similarly shape men's political participation. For example, Thomas argues that male leaders in Chile constructed their qualifications as political leaders by invoking specific paternal frames (Thomas, Contesting Legitimacy). 
of maternalism. Political women can appeal to different meanings of maternalism, or deny them altogether, in response to these varied contexts.

The typology thus illustrates important trends in the changes, continuities and tensions around maternalism in Latin America today. First, all female political leaders must address, explicitly or implicitly, how feminine characteristics, particularly those related to motherhood, are suitable for public office. The tensions between maternalism and equality discourses are perhaps greatest for women contesting chief executive office: in Latin America's strong presidential systems, societal expectations privilege men, who, by virtue of their sex, are presumed to possess the leadership capacities (assertiveness and decisiveness) that their female competitors are presumed to lack. The prominence of congressional candidates varies according to the electoral system (i.e. whether single-member or multi-member district), but congressional candidates generally enjoy less visibility than presidential candidates. Once in office, expectations about presidents and legislators continue to differ. Legislators are expected to work collectively and cooperatively, whereas chief executives often act unilaterally and are expected to behave authoritatively. Consequently, the usefulness of maternal frames may depend on the office.

Yet across offices, our categories highlight the different ways that female politicians negotiate their participation in what remains a traditionally masculine activity. Second, these cultural frames are used with different frequencies, again illustrating their role as strategic, context-specific resources, not fixed personality types. Our interviews show that, in certain moments and in certain political offices, women will emphasise or minimise their familial identities, their policy expertise or their capacity for taking tough decisions.

\section{The Traditional Supermadre}

In this category, women justify their entry into politics with straightforward appeals to their maternal identities, implicitly supporting the primacy of women's traditional roles. Traditional supermadres construct public profiles in which they are identified as self-sacrificing and driven to enter politics because their caring and nurturing qualities are needed. Nicaragua's Violeta Chamorro exemplifies this category. Running in I 990 against Sandinista candidate, Daniel Ortega, Chamorro deployed a narrative where her maternal identity compelled her into politics; she was responding to the extraordinary circumstances created by political crisis, namely, civil war and political instability. Chamorro's campaign centred on her martyred husband, Pedro Joaquín Chamorro, and her family. Her campaign utilised the symbols of 'wife, widow, mother, and virgin'; she claimed that, as a mother, she had the leadership necessary to 'reconcile the Nicaraguan people, torn by more 
than a decade of war' ${ }^{74}$ Chamorro used maternalism to argue that she offered Nicaraguans the best hope for peace and political reconciliation.

A contemporary example of the traditional supermadre is Josefina Vazquez Mota, who sought the Mexican presidency in 2012 in the context of an increasingly violent and fatiguing drug war. Outgoing president Felipe Calderón had mismanaged the security situation, leaving his party, the Partido Acción Nacional (PAN), severely discredited going into the $20 \mathrm{I} 2$ race. As the PAN's candidate, Vazquez was 'put forward as the nurturing, soothing, national caretaker who will put the house back in order'. ${ }^{75}$ Though Vazquez shared her party's get-tough approach to drug traffickers, she distanced herself from Calderón's excessive militarism and instead emphasised her commitment to fighting corruption, a policy platform consistent with perceptions of women as the 'cleaners' of the national house.

Like the supermadres Chaney interviewed in the i950s and 1960s, Vazquez emphasised her status as a Catholic, a wife and a mother, but she also updated this version of maternalism. In a much-covered incident, when her opponent (and ultimate victor), Enrique Peña Nieto, deflected a female journalist's question about inflation on the price of regular goods with the dismissive comment that 'he wasn't the woman of the house', Vazquez seized an opportunity to validate women's traditional responsibilities: 'I am a woman, I am a housewife, I am a government official, I've been twice a government secretary, I've been leader of a parliamentary group, I am an economist. Although we may not be there for many hours, as in my case, and I'm sure your case and many others of us, every night we return to the kitchen to check the refrigerator and see if everything is ready or what needs to be bought the next day'. ${ }^{6}$ Thus, Vazquez highlighted her professional credentials while emphasising that she never abandoned her domestic duties, and that she recognised the unique insights women gain through their roles as wives and mothers. This commitment signalled her closeness to everyday working and professional women who, despite daily absences from the home, ensure its proper functioning.

Further, as Chaney wrote, good mothers and wives address crises affecting the family, especially the national family. The traditional supermadre frame thus also appears among female legislators, many of whom legitimise their careers by appealing to national crises. For example, Argentine legislators report being motivated by their country's political and economic upheaval in 200I and 2002: one explained that, 'a moment arrived to renovate and reconstruct politics, to use politics as a tool of social transformation' and another

${ }^{74}$ Kampwirth, 'The Mother of the Nicaraguans', pp. 72, 67.

75 Joclyn Olcott, quoted in Randal C. Archibold, 'Nomination Paves New Path in Mexico', New York Times, 6 February $20 \mathrm{I} 2$.

${ }^{76}$ Archibold, 'Nomination Paves New Path in Mexico'. 


\section{Franceschet, Piscopo and Thomas}

noted that the economic disaster spurred her 'to save the country, restore basic necessities for society'. ${ }^{77}$ Another believed that women must introduce 'a politics of care' to the country. ${ }^{78}$ These traditional supermadres view their skills as mothers and nurturers as helping them find political solutions to widespread suffering.

\section{The Technocratic Caretaker}

This frame prioritises gender equality over women's identities as mothers while maintaining a broader emphasis on public care work. Like the more modern supermadre exemplified by Vazquez, this frame allows female politicians to emphasise their policy credentials; however, this frame also allows female politicians to reject the supermadres' notion that private caretaking roles constitute women's primary identity. Framing themselves as technocratic caretakers permits female politicians to draw on experiences that emerge from the gendered division of labour, which give women unique insights into the policy problems confronted by women, families and society. These policy insights are constructed in feminine, but not necessarily maternal, terms. Thus, technocratic caretakers, unlike traditional or modern supermadres, explicitly champion gender equality while prioritising policy issues easily framed through ideals of care like health or education.

The 2005 campaign of Michelle Bachelet in Chile is particularly illustrative. Bachelet's vocal commitment to gender equality and her willingness to confront sexism in politics make her unique among the region's presidents. As a candidate, Bachelet directly challenged the masculine bias inherent in expectations about political leadership and argued for a broader conceptualisation that included traits and characteristics considered feminine. A television spot exemplified this approach: in the ad, Bachelet praised women's ability to excel as workers and scientists while balancing the needs of their families. She concluded, 'Strength knows no gender, and neither does honesty, conviction or ability. I bring a different kind of leadership, with the perspective of someone who looks at things from a different angle. Let us change our mentality; when all is said and done, a woman president is simply a head of government who doesn't wear a tie'. 79

Yet Bachelet did not justify her political vocation in terms of her maternal identity or her unique capacities to resolve crises or combat corruption. Nor did she present herself as apolitical. Instead, she drew upon her experiences as a single mother and head-of-household to claim a broader understanding of the everyday lives, concerns and struggles of Chileans, especially women.

\footnotetext{
77 Author interviews, Argentina, 23 April 2009, and 13 Aug. 2014.

${ }_{78}$ Author interview, Argentina, 2 I Aug. 2014.

79 Televised Bachelet ad, aired I January 2006.
} 
She highlighted the political relevance of everyday caring roles and responsibilities. She balanced her portrayal of 'feminine leadership' with her educational achievements (a medical doctor fluent in five languages) and her past political experience, particularly as minister of defence.

Despite Bachelet's nuanced portrayal of her political leadership and policy priorities, her opponents and the media often painted her in more traditional ways. Once in office, she was called la madre de la nación, and some political commentators linked her high approval ratings to the cariñocracia (caringocracy) that she created through her personal likability. ${ }^{80}$ This maternal framing, promoted by political pundits and opposition politicians, contributed to a broader pattern of attacking Bachelet for lacking strong and decisive leadership. Instead of attributing her popularity to her leadership skills and successful policies, commentators implied that Chileans supported Bachelet because of her caring, likeable personality. ${ }^{8}$ Despite Bachelet's own efforts to emphasise her talents and skills, cultural expectations around women's maternal qualities and the masculinity of executive office influenced perceptions of her presidency.

Female legislators also strategically deploy the technocratic caretaker frame to balance equality with more traditional ideas about women's roles. Many female interviewees emphasised their credentials and skills, noting that their qualifications and abilities, including long periods of public service, made them equal to men. Yet they also framed their political identities as emerging from experiences that link women more tightly than men to the nation's social fabric. For instance, an Argentine legislator mentioned motherhood when explaining roll call voting: 'I think about my accountability as a mother: how will I justify to my daughter my efforts to make this country better?' She added that she did not believe male legislators viewed accountability in terms of their generational and parental responsibility. Similarly, her colleague stated, 'I do this for a better world for my son'. ${ }^{82}$

This notion of women's unique sensibility for caring and empathy dominated most legislators' explanations of policy-making, though interviewees tied this connection to their female identities generally, rather than their maternal identities specifically. Mexican legislators made statements such as: 'Women have a unique vision of endurance and suffering ... it is women's overall vision'; 'women are closer to the people and have policies focused on society'; and women more easily 'see the problems society faces'.$^{8} \mathrm{~A}$

${ }^{80}$ Patricio Navia, 'La cariñocracia de Bachelet', La Tercera, 4 July 2009. Available at www. latercera.cl (accessed 26 December 2009).

${ }^{81}$ Thomas, 'Michelle Bachelet's Liderazgo'; Teresa Valdés, 'El Chile de Michelle Bachelet ¿Género en el poder?', Latin American Research Review, 45 (2010) pp. 248-73.

82 Author interviews, Argentina, 21 April 2009, and 13 Aug. 2014.

${ }^{83}$ Author interviews, Mexico, 2, 8, and 9 Dec. 2009. 
Chilean deputy noted that women's views of politics were more 'oriented to the common good ... more grounded' and that this orientation made them less partisan than their male colleagues and more open to working with legislators from other parties. ${ }^{84}$ Others explained their policy preferences by saying that 'women are more empathetic' or women have more interest in 'people at the margin [of subsistence], of marginality' because of their greater connection to the social fabric. ${ }^{85}$

These comments reveal a perspective informed by both cultural ideals and women's social experiences: technocratic caretakers combine classically feminine notions of caretaking with detailed understandings of policy. This frame portrays feminine ideals as sources of policy-making expertise and strength, one also expected by constituents. As one Argentine deputy explained, 'women have greater sensibility in the areas of health, poverty, handicapped people, and the elderly, but women also receive a political mandate, it is our political responsibility to represent these themes, because the voters demand more social policy work from women than men'. ${ }^{86}$ Another explained, 'women have a doble cargo [double duty]: they must know every policy area that men know, and they must know women's issues, too' ${ }^{87}$ This comment indicates how technocratic caretakers understand that, while women may not explicitly be required to mother the nation, they are still expected to care for the disadvantaged.

Thus, unlike traditional supermadres, female politicians positioning themselves as technocratic caretakers do not justify political careers through motherhood. Being women and mothers conveys politically and socially relevant dimensions of their identity, but these identities do not legitimise their public presence and may be adopted strategically. Many 'technocratic caretakers' also identify gender equality and women's rights as policies of great importance, and insist that they are just as qualified as men to occupy public office. Yet technocratic caretakers also know that society, still influenced by maternalism, assigns women primary caretaking responsibilities, and they position themselves accordingly.

\section{The Macho Minimiser}

Women in this category display few of the nurturing, compassionate traits that traditional gender norms prescribe for women. Although assumptions about women's skills and appropriate behaviour affect all female officeholders, the presidency creates particularly intractable double binds for women: the more

${ }^{84}$ Author interview, Chile, 8 Nov. 2006.

${ }^{85}$ Author interviews, Mexico, 8 Dec. 2009, and Argentina, 25 March 2009.

${ }_{86}^{86}$ Author interview, Argentina, 23 April 2009.

${ }^{87}$ Author interview, Argentina, is April 2009. 
they display traditionally masculine traits like decisiveness and toughness, the less feminine they appear. ${ }^{88}$ Faced with intense scrutiny, particularly by the media and their competitors, female presidents and presidential contenders attempt to soften their image by deploying frames that minimise characteristics perceived as masculine and that emphasise markers of traditional femininity.

In Brazil, for example, Dilma Rousseff's first presidential campaign struggled to balance her assertiveness (a culturally masculine trait) with her compassion (a culturally feminine trait). On the one hand, she enjoyed a favourable reputation as a tough leader and sharp analyst: a former guerrilla, she had considerable policy credentials from past posts in traditionally masculine areas such as energy and the economy. On the other hand, critics' portrayal of her as 'intransigent' and 'abrasive' prompted strategists to soften this image: for instance, the birth of a grandchild became an opportunity to highlight her caring credentials. As part of the macho minimiser frame, Rousseff's campaign further labelled her 'the mother of the nation' or 'the mother of Brazil', paralleling images of her predecessor, Luiz Inácio da Silva, who was known as the 'father of Brazil'. ${ }^{89}$

Similarly, Cristina Fernández de Kirchner in Argentina ran two successful campaigns based on her assertive character and her policy record, which included the deliberate eschewing of women's issues or maternal framing. Yet media analysis revealed that newspapers carried stories about how she dominated male participants in policy sessions. ${ }^{\circ}$ Journalists also avidly discussed her fashion choices, her hairstyle and her overall aura of glamour. Fernández clearly cultivated this image herself: she adopted dress, speech patterns and behaviours that evoked the great Argentine icon, childless Evita Perón, who claimed to love Argentines as she would have loved her own children. Like Rousseff, Fernández strategically offset a strong management style with traditional markers of femininity, rejecting some gender stereotypes while conforming to others.

This ideal type appears less pronounced among female legislators, perhaps because congresswomen spend less time in the public eye. However, several lawmakers described their leadership styles as mixing masculine and feminine elements. One Mexican senator explained that 'she used a maternal style but also a firm style'. ${ }^{11}$ An Argentine legislator praised her own toughness and

${ }^{88}$ Rainbow Murray (ed.), Cracking the Highest Glass Ceiling: A Global Comparison of Women's Campaigns for Executive Office (Santa Barbara, CA: Praeger, 2010).

${ }^{89}$ Pedro G. dos Santos and Farida Jalalzai, 'The Mother of Brazil: Gender Roles, Campaign Strategy, and the Election of Brazil's First Female President', in Maria Raicheva-Stover and Elza Ibroscheva (eds.), Women in Politics and Media: Perspectives from Nations in Transition (New York: Bloomsbury, 2014), pp. 167-88.

90 Mariana Verón, 'Cristina Kirchner Endorsed the Business Sector', La Nación, 5 Sept. 2007; Silvia Naishtat, 'An Encounter with Economic Definitions', Clarin, 5 Sept 2007.

${ }^{91}$ Author interview, Mexico, 8 Dec. 2009. 
assertiveness during policy negotiations, but also believed that men will dominate conversations while women, such as herself, more typically 'get along with others'. $9^{2}$

\section{The Difference Denier}

Some female politicians reject the notion that cultural norms of gender separate men and women or result in unequal treatment of men and women. This frame emphasises the progress made towards women's equality, with female politicians using their own experiences as evidence that genderbased discrimination is fast disappearing from public life. In this category, female politicians avoid explicit references to either maternalism or gendered traits and roles.

For example, Laura Chinchilla's presidential campaign downplayed her status as a woman and possible first female president. She presented herself as a strong and firm leader, with campaign slogans such as, Laura adelante (Onward Laura) and Laura firme y honesta (Laura firm and honest). Her central campaign issues were combating crime and vigorously prosecuting drug trafficking, which built on her previous posts as vice-minister and minister of public security, minister of justice, and vice-president. Unlike Rousseff and Fernández, she did not strategically soften her image. She addressed her status as a woman only once in her television ads, in response to a television ad from opponent Ottón Solís. This ad presented Chinchilla as a marionette controlled by outgoing president Óscar Arias, his brother Rodrigo Arias and a shadowy figure perhaps representing a narco-trafficker. Chinchilla's response cast the ad as not just a personal attack, but as a broad assault on women's political abilities: yet she asserted that 'all women deserve respect' without mentioning issues of sexism. ${ }^{33}$ Chinchilla also distanced herself from feminism, the women's movement, and the struggle for women's equality in Costa Rica. ${ }^{94}$

Female legislators also adopt the difference denier frame. A Chilean deputy noted that her own conservative party 'is one of the parties with the most female deputies, female mayors, and female councillors'. She viewed women's political under-representation as a result of women's unwillingness to run, not parties' sexism: 'I think that more than discrimination by parties, it's a self-discrimination by women, of not wanting to confront [it], to raise money, to make a campaign, put together a team, and expose themselves to being in the media ... But when there is a female candidate, in

92 Author interview, Argentina, 13 Aug. 2014.

${ }^{3}$ Author analysis of spot; Juan Pablo Sáenz Bonilla and Oscar Mario Jiménez Alvarado, 'La política televisada: análisis de los spots publicitarios en la campaña electoral 2010', Revista de Ciencias Sociales, 4: 130 (2010), pp. I 17-29.

${ }^{94}$ Author interview, Costa Rica, 28 Feb. 2013. 
general, the voters receive her very well'. 95 Likewise, another Chilean legislator regarded her conservative party's selection process as very democratic: though 'one has to pass through many stages, and that isn't very easy', she insisted that what mattered was whether one was a good candidate, not whether one was a woman. In her own case, she believed that being a woman was 'neither an advantage nor a disadvantage'. ${ }^{96}$

Difference deniers are thus unwilling to acknowledge either the structural barriers or sexism women face in their careers. An Argentine legislator said, 'There is no discrimination against women, today we are 30 per cent'. 97 Likewise, her colleague insisted that sexism has never affected her career, though 'intellectually, I know it could exist'. ${ }^{8}$ Another Argentine deputy explained, 'women no longer have taboos, women are able to discuss all the themes. Yes it is difficult to build a political career as a woman, but female and male legislators are equal and there is no sexist or machista treatment. Women have demonstrated that they can stand shoulder to shoulder with men'.99

The difference denier frame may help women counter perceptions that they attained their posts through affirmative action rather than merit. Women, particularly right-leaning women like Chinchilla, may also wish to distance themselves from feminism, which remains controversial. Yet as discussed earlier, structural barriers to women's, and mothers', presence in politics clearly exist. Difference deniers most likely find ignoring these barriers to be the best strategic choice.

Thus maternalism, even in its absence or rejection, still influences the cultural narratives through which female politicians are perceived by their broader society; these narratives, in turn, shape female politicians' options for selfpresentations. To enter national politics, women must negotiate their connections to the private sphere, domesticity and caretaking. Our categories identify four ideal-type responses to maternalist ideologies, wherein female politicians choose a public performance that they believe 'fits' with larger cultural attitudes and their own political strengths and experiences. These options entail embracing, redefining or rejecting maternalism.

Importantly, based on our interviews and media analysis, we find that most female politicians have opted for redefinition: the technocratic caretaker category predominates over the traditional supermadres, the macho minimisers and the difference deniers. While political women no longer exclusively present themselves as apolitical mothers or as selfless defenders of their

95 Author interview, Chile, 24 July 2002.

${ }_{96}^{6}$ Author interview, Chile, 8 Nov. 2006.

97 Author interview, Argentina, 5 Aug. 2014.

${ }_{98}$ Author interview, Argentina, 6 Aug. 2009.

99 Author interview, Argentina, 13 Aug. 2014. 
families, feminine ideals of compassion and caretaking still shape cultural narratives that provide female politicians with options to legitimise their careers and explain their policy goals.

\section{Conclusion}

Throughout this article, we have argued that neither the increasing number of women in elected office nor the growing saliency of equality discourses have displaced the cultural and structural aspects of motherhood that shape women's experiences in politics. In Latin America, maternalism has unique historical legacies: while female politicians worldwide commonly confront structural barriers and cultural expectations related to their assigned caretaking roles, ${ }^{100}$ female politicians in Latin America can draw on a long history of political activism grounded in maternalism to claim a space in public. Our analysis links contemporary manifestations of maternalism to Latin America's historical context. We analyse the structural constraints imposed on women's political careers by their caretaking roles, discussing how maternal ideals historically created a 'supermadre' or 'militant mother' frame that uniquely legitimated women's political careers. Our typology captures how these perceptions and realities of maternalism have influenced women's understandings and justifications of their political roles in the democratic era.

We see that Latin American women are challenging the relationship between motherhood and politics, thus reimagining the importance of maternal ideals. Female politicians now report myriad motivations for political action, and motherhood is neither the sole nor dominant justification for women's political participation. Most important, women are no longer positioned as being 'above politics' until a crisis provokes them to use their caretaking abilities for the public good. In earlier historical periods, this view meant that women's political activism was sporadic rather than routine. Today, elected women justify their careers by appealing not just to their life experiences as mothers and family caretakers, but to their professional backgrounds, leadership skills and qualifications.

Presidential campaigns and presidencies provide the most evidence for this change. Given the hyper-masculinity associated with executive office, successful women have emphasised their professional skills and leadership qualities in order to establish their credentials. Yet, female presidential candidates face continued expectations that motherhood should influence women's political interests and activism. As a result, they adopt strategic frames that emphasise their competence in caretaking, or their feminine traits such as compassion or beauty. Thus, women have redefined executive office in ways that

${ }^{100}$ Amanda Bittner and Melanee Thomas (eds.), Mothers and Others (Vancouver: University of British Colombia Press, forthcoming). 
accommodate certain maternal identities and feminine traits. Likewise, female legislators use maternalism and femininity to define their policy-making expertise, or they use their professional credentials to justify their careers; some even reject ideas of sexism or gender difference.

Indeed, the four ideal types we identify reveal the fractured and complicated terrain that female politicians navigate. The continued cultural emphasis on and structural barriers related to motherhood, combined with growing acceptance of women's presence in public life, means female politicians face a balancing act: they must gain credibility and power on masculine terms by being seen as serious and competent as men, yet they feel compelled to bring their feminine perspectives to politics. To understand women's current presence in Latin American politics, scholars must acknowledge the continued resonance of motherhood, particularly the intersection of maternal identities with other identities related to profession, socio-economic status, class, and race and ethnicity. Indeed, further research on the nexus between maternalism, political ambition and career pathways should explore how these ideal types vary for women of differing class, ethnic and racial backgrounds.

Unfortunately, this complicated terrain does not resolve the long-standing debate over whether or not maternalism, in emphasising traditional gender roles, hinders women's equality. On the one hand, emphasising motherhood or denying difference may preclude activists from making feminist demands regarding women's rights. If motherhood remains the central frame through which women gain access to national-level politics, and through which policy-makers address women's interests, then women's economic, educational and reproductive equality may be difficult to address. Even in democratic Latin America, legal codes still lack full guarantees for equal pay and reproductive choice, and welfare regimes still reinforce a male breadwinnerfemale homemaker model. On the other hand, initial worries that maternalism would prevent women from active democratic participation have not been realised. Women have clearly advanced towards equality throughout the region. Maternal ideals now serve to illustrate why women's perspectives, emerging out of their social experiences, need representation in formal politics, signalling the ongoing power of motherhood and maternalism within Latin American societies.

\section{Spanish and Portuguese abstracts}

Spanish abstract. Elsa Chaney argumentó una vez que las mujeres latinoamericanas utilizaron la figura de maternidad para justificar su participación política. Ahora que las mujeres latinoamericanas han logrado un acceso sin precedente a cargos públicos nacionales, nos preguntamos si estas narrativas culturales maternales todavía condicionan el acceso al poder político de las mujeres en política. Utilizando información proveniente 


\section{Franceschet, Piscopo and Thomas}

de la opinión pública, del análisis de medios de comunicación, y de las entrevistas a las élites, conceptualizamos cuatro marcos estratégicos desplegados por mujeres de élite para justificar sus carreras políticas de nivel nacional: la supermadre tradicional; la cuidadora tecnócrata; la 'macho minimiser', una posición que minimiza las características masculinas; y la 'difference denier', una posición que niega totalmente las diferencias de género. Argumentamos que mientras las mujeres en la política han desarrollado diversas respuestas al maternalismo, su acceso a cargos públicos sigue estando profundamente afectado por limitaciones estructurales y narrativas culturales que privilegia ideales femeninos tradicionales de cuidadoras de otras personas.

Spanish keywords: género, política, mujeres, maternidad, Latinoamérica

Portuguese abstract. Elsa Chaney anteriormente propôs que as mulheres latinoamericanas recorreram à maternidade para justificar sua participação política. Agora que as mulheres da América Latina conquistaram em números sem precedente a cargos políticos de nível nacional, perguntamos se essas narrativas culturais sobre a maternidade ainda condicionam o acesso de mulheres ao poder. Utilizando-se de dados de opinião pública, análises de mídia e entrevistas com ocupantes de cargos de alto escalão, criamos quatro categorias de estratégias empregadas por mulheres na política para justificar suas carreiras políticas de nível nacional: a tradicional supermadre, a cuidadora tecnocrática, a minimizadora da masculinidade e a negadora de diferenças. Argumentamos que apesar das diversas repostas ao maternalismo desenvolvidas pelas mulheres na política, o acesso delas a cargos públicos permanece profundamente moldado por restrições estruturais e narrativas culturais que privilegiam ideais tradicionais do zelo feminino.

Portuguese keywords: gênero, política, mulheres, maternidade, América Latina 